\title{
Influence of the substrate composition on the yield and nutritional value of the fruiting bodies of the edible mushrooms Pleurotus citrinopileatus and Cyclocybe aegerita
}

\author{
I. I. Bandura ${ }^{1 *}$, A. S. Kulyk ${ }^{1}$, S. V. Makohon ${ }^{1}$, 0. V. Khareba ${ }^{2}$, V. V. Khareba ${ }^{2}$ \\ ${ }^{1}$ Dmytro Motorny Tavriya State Agrotechnological University, 18 Bohdana Khmelnytskoho Ave., Melitopol, Zaporizhia region, \\ 72312, Ukraine, *e-mail: irabandura@gmail.com \\ ${ }^{2}$ National Academy of Agrarian Sciences of Ukraine, 9 Mykhaila Omelianovycha-Pavlenka St., Kyiv, 01010, Ukraine
}

Purpose. To reveal the influence of the substrate compositions on technical indicators and the chemical composition of the fruiting bodies of the golden oyster mushroom and poplar mushroom. Methods. The experimental design included cultivation of two species of wood-decay fungi Pleurotus citrinopileatus Singer (strain 2161 IVK) and Cyclocybe aegerita (V.Brig.) Vizzini (strain 2230 IVK) on three variants of substrate composition. Laboratory, laboratory-production methods for evaluating the effectiveness of growing technology, chemical composition of the obtained raw materials, statistical methods of analysis were applied. Results. The structure and composition of substrates affect the technological characteristics of the culture, physical and chemical properties of fruiting bodies. The shortest fruiting cycle of $35.2 \pm 1.7$ days was determined for $C$. aegerita under growing conditions on SC1 substrate which formula included «straw, husks, pellet, rapeseed, corn, and $\mathrm{CaCO}_{3}$ » in the ratio of 30: 40: 70: 20: 20: 1 . The highest yield (170.5 $\pm 15.2 \mathrm{~g}$ per $1 \mathrm{~kg}$ of substrate) in the experiment was determined for $P$. citrinopileatus on the SC1 substrate composed of «straw / pellets / rapeseed / corn / $\mathrm{CaCO}_{3}$ » in the ratio 40: 90: 20: 25: 1 . Fruiting bodies of $P$. citrinopileatus obtained from the SC3 substrate composed of «pellets / rapeseed / corn / $\mathrm{CaCO}_{3}$ » in the ratio 60: 110: 20: 30: 1 had the highest protein content $-22.47 \pm 0.19 \%$, and fruiting bodies from the SC1 substrate had the least amount of proteins $-17.38 \pm 2.60 \%$. Fruiting bodies of $C$. aegerita contained more lipids than those of $P$. citrinopileatus, but the factor of the influence of the substrate composition on the total amount of lipids for some cultivars was insignificant. The largest amount of endopolysaccharides was isolated from the fruiting bodies of $C$. aegerita $(6.81 \pm 0.41 \%)$ cultivated on SC3 substrate, and the smallest in the SC1 variant $(1.38 \pm$ $0.25 \%$ ). The content of endopolysaccharides in the fruiting bodies of $P$. citrinopileatus had less variability from $2.54 \pm 0.54$ (SC3) to $4.72 \pm 0.61 \%(\mathrm{SC} 1)$. Conclusion. Substrate compositions significantly affect the biological efficiency of cultivars and the content of nutrients in fruiting bodies of the studied species. The obtained results enable producers of mushrooms to predict the production efficiency and quality of grown mushrooms in accordance with the use of available raw materials.

Keywords: cultivation of mushrooms; golden oyster mushroom; poplar mushroom; biological effectiveness; chemical composition.

\section{Introduction}

Exotic mushrooms have already become an integral part of functional diets due to the con-

Iryna Bandura

http://orcid.org/0000-0001-7835-3293

Alina Kulyk

http://orcid.org/0000-0001-5403-3084

Serhii Makohon

http://orcid.org/0000-0002-4791-5115

Olena Khareba

https://orcid.org/0000-0002-6763-1988

Volodymyr Khareba

https://orcid.org/0000-0001-9947-2689 tent of bioactive substances with proven nutritional and medicinal value. In Asian countries, which are leaders in the production and consumption of mushrooms, wood-decay fungi are preferred, and shiitake and various species of oyster mushrooms are popular: oyster mushroom, king oyster mushroom, Lung Oyster and others. But in recent years, the demand for golden oyster mushroom Pleurotus citrinopileatus Singer («Gold mushroom») and poplar mushroom Cyclocybe aegerita (V.Brig.) Vizzini, known in Europe and America as "velvet pioppini» has been growing rapidly $[1,2]$.

The golden oyster mushroom is appreciated for its bright, rich yellow color of the cap and the 
specific light and pleasant aroma of seafood, which appears after a short thermal treatment [3]. Fruiting bodies of this fungus contain $22.10 \pm 2.03 \%$ of protein, and in the biomass obtained by submerged cultivation, protein content reaches $36.2 \pm 1.2 \%[3,4]$. According to published data [5], the amount of lipids varies from 1.32 to $3.37 \%$, but does not exceed $5 \%$. Such interesting dietary features of $P$. citrinopileatus are complemented by the content of substances with high medicinal potential, for example, the nonlectin glycoprotein (PCP-3A) found in fresh fruiting bodies [6]. Researchers [7, 8] emphasize the high antitumor ability of glycoproteins of this species of oyster mushroom, as well as their antioxidant and hypoglycemic properties.

The poplar mushroom is firm in texture and keeps the shape and structure of fruiting bodies after boiling; mushrooms remain dense and crisp, retaining the dark color of the cap [9]. But in addition to high nutrition indicators, the fruiting bodies of poplar mushroom contain unique ceramides with proven antitumor potential [10]. The antioxidant properties of the extracted polysaccharides and their ability to stabilize skin collagen were discovered. That reveals the prospects for the use of these substances as natural agents or food additives in gerontological practice and for combating agerelated complications [11].

Bright and rich colors of fruiting bodies of golden oyster mushrooms and poplar mushrooms always attract consumers. On the other hand, these species have repeatedly proven nutritional and medicinal value, which makes them an integral part of health food in Asia and $\mathrm{Eu}$ rope [1-4]. The price of these mushrooms is an order of magnitude higher in comparison with the already known button mushroom champignons and oyster mushrooms, what determines the interest of mushroom producers in growing these species. The domestic adaptation of the known regulations for the cultivation of golden oyster mushrooms and poplar mushroom is significantly slowed down in the absence of information about the possibility of using available agricultural by-products and its effect on the quality of mushroom products. Researchers emphasize the significant influence of substrate compositions and methods of their preparation on the technical indicators of growing mushroom culture, on the content of organic and mineral substances in mushrooms, which, accordingly, changes their taste and aroma [3, 4]. In particular, scientists from Kenya determined that the formation of $P$. citrinopileatus primordia began on the 13 th day from the moment of inoculation on bean straw substrate, while on the sawdust substrate - on the 31st; the biological efficiency of the culture was $149 \%$ from the bean straw substrate and decreased to less than $1 \%$ when sawdust was used [4]. Enrichment of wheat straw substrates with poultry litter and millet grains allowed researchers from the United States to increase the biological efficiency of C. aegerita cultivation fivefold. In the same experiment, the optimal ratio of $70: 10: 20$ components in the substrate formula «straw / litter / millet» contributed to the increased protein content in the fruiting bodies of C. aegerita to $37.6 \%$, while on the substrate made of wheat straw this indicator was $27.1 \%$ [12-14].

The main components of substrates for artificial cultivation of $P$. citrinopileatus and C. aegerita are cereal straw and sunflower husk, which cost increases annually and significantly depends on logistics. Previous studies showed the possibility of using fuel pellets made from sunflower husks to increase the efficiency of growing wood-decay fungi [15]. But the high density of such raw materials leads to a decrease in the aeration characteristics of the substrates, which can affect the physiological and biochemical parameters of the culture.

The purpose of the study is to reveal the effect of substrate composition content on the technical and chemical parameters of fresh fruiting bodies of golden oyster mushroom (P. citrinopileatus) and poplar mushroom (C. aegerita).

\section{Materials and methods}

The cultures of the studied species - strains of $P$. citrinopileatus $2161 \mathrm{IVK}$ and $C$. aegerita 2230 IVK, were obtained from the collection of cap mushrooms cultures of the M. G. Kholodny Institute of Botany and maintained on a nutrient medium of the following composition: $20 \mathrm{~g}$ agar-agar, $20 \mathrm{~g}$ malt-dextrose, $2 \mathrm{~g}$ dry yeast extract, up to 1 liter water. The $\mathrm{pH}$ of the medium was adjusted to $6.7 \pm 0.2$ with $0.1 \mathrm{~N} \mathrm{KOH}$ solution and sterilized for $35 \mathrm{~min}$ at $121{ }^{\circ} \mathrm{C}$ [16].

For the manufacture of substrate compositions, the following components were used: local raw materials - barley straw and sunflower husks crushed to $5-7 \mathrm{~mm}$, as well as fuel pellets from husk. The composition of the substrate compositions was calculated so as to achieve a carbon to nitrogen $(\mathrm{C}: \mathrm{N})$ ratio of $20: 1$, in accordance with published data [17]. Rapeseed was added to the formula to provide the required lipid content [18]. Also, the formulas of the compositions were calculated so as to achieve the optimal values of moisture indicators $(63-65 \%)$ and substrate density 
from 350 to $550 \mathrm{~kg} / \mathrm{m}$ [15]. The required water content was calculated taking into account the initial moisture content of the raw material (Table 1).

The ratio of the components of the substrate compositions (SC) by weight (kg)
\begin{tabular}{|l|c|c|c|c|c|c|c|}
\hline Composition code & Straw & Husks & Pellets & Rapeseed & Corn & Chalk $\left(\mathrm{CaCO}_{3}\right)$ & Water \\
\hline SC1 & 30 & 40 & 70 & 20 & 20 & 1 & 263 \\
SC2 & 40 & 0 & 90 & 20 & 25 & 1 & 325 \\
SC3 & 0 & 60 & 110 & 20 & 30 & 1 & 288 \\
\hline Moisture, \% & 11.5 & 8.8 & 7.5 & 10.5 & 7.8 & 12.3 & 100 \\
\hline
\end{tabular}

Straw, husks and rape plant seeds were soaked with an excess of cold water for 8-10 hours. The moistened raw materials were put into mixing containers. Pallets were prepared separately: warm water $\left(30-40{ }^{\circ} \mathrm{C}\right)$ was added, the moist components were mixed adding ground corn and chalk. The finished compositions were packed in polypropylene bags $580 \times 480 \mathrm{~mm}$, with four filters in the upper part measuring $20 \times 480 \mathrm{~mm}, 3250 \pm 50 \mathrm{~g}$ each. The substrates were sterilized in an industrial autoclave at $121 \pm 3{ }^{\circ} \mathrm{C}$ for $120 \mathrm{~min}$. The substrates, cooled to a temperature of $26 \pm 1{ }^{\circ} \mathrm{C}$, were inoculated under aseptic conditions with mycelium-covered cereal at $3 \%$ by weight $(100 \pm 15 \mathrm{~g}$ per bag). For each variant of the experiment, 30 bags were made. Substrate samples were taken after inoculation (from five bags of $50 \mathrm{~g}$ each) and mixed. The averaged sample was used for analysis.

The density of the substrate was determined by the formula:

$\rho=m / V$,

where $\rho$ - density of the substrate, $\mathrm{kg} / \mathrm{m}^{3}$; $m$ - mass of the substrate, $\mathrm{kg} ; V$ - volume of a unit of the substrate, $\mathrm{m}^{3}$.

The volume of the substrate block was determined by the formula:

$V=\pi \times a \times b \times h$,

where $\pi-3.14 ; a-$ the semi-major axis of the package after installation on the shelf had the shape of an ellipse, $\mathrm{m} ; b$ - semi-minor axis, $\mathrm{m} ; h$ - substrate height, $\mathrm{m}$.

The moisture content of plant raw materials and manufactured substrates was determined gravimetrically at a temperature of $102 \pm 1{ }^{\circ} \mathrm{C}$, but the samples of fruiting bodies were first dried at a temperature of $45{ }^{\circ} \mathrm{C}$, taking into account the characteristics of the mushroom raw material, and then dried to an absolutely dry mass at $92 \pm 2{ }^{\circ} \mathrm{C}$.

The concentration of hydrogen ions $(\mathrm{pH})$ of the substrate was determined according to national standard DSTU ISO 10390: 2007 Soil quality. Determination of pH (ISO 10390: 2007, IDT).

The ash content was determined as follows: $3 \mathrm{~g}$ of absolutely dry powder of the fruiting body were weighed in ceramic crucibles of known weight, burned in a muffle furnace at a temperature of $550 \pm 10{ }^{\circ} \mathrm{C}$ for three hours, and the samples were cooled in a desiccator. The ratio of the residual mass to the original mass of the sample in percent was calculated.

The total nitrogen content was determined by the chloramine method according to Pochinok.

The $\mathrm{C} / \mathrm{N}$ ratio was determined by the formula $C / N=0.5(100-a) / N$, where $a$ - the ash content, $\% ; 0.5$ - coefficient of carbohydrate content, adjusted for the biochemical characteristics of raw materials; $N$ - the content of total nitrogen in the substrate [20].

The analysis of the technical parameters of the substrates and the chemical analysis of the fungi were carried out in triple repetition for each cultivation cycle.

The substrates were incubated at a temperature of $23 \pm 3{ }^{\circ} \mathrm{C}$ and a humidity of $65 \%$ indoors. Lighting was used only to control the development of a culture.

Fruiting was initiated from the 20th day. The packages were placed in a growing chamber with appropriate microclimatic conditions: air temperature $14 \pm 1{ }^{\circ} \mathrm{C}$, relative air humidity $91 \pm 5 \%$; carbon dioxide content $1250 \pm 150 \mathrm{ppm}$ $(0.12 \%)$. Illumination was maintained at 150 200 lux for $8 \pm 1$ hour per day. Taking into account the different level of shelves on rackes regarding the floor and the possible difference in microclimatic conditions, the packages were installed randomly. Two $100 \pm 20 \mathrm{~mm}$ cuts were made on the bags with $P$. citrinopileatus culture, but the substrate was not freed from the film. On the bags with the C. aegerita culture, a cut was made in the upper part and a polypropylene film was peeked back to the side (Fig. 1). The crop was harvested at the stage of technical maturity before the onset of sporulation.

Fresh fruiting bodies for biochemical analysis were collected from different blocks in accordance with the variant of the experiment, dried at a temperature of $55 \pm 3{ }^{\circ} \mathrm{C}$ for $8-10$ hours and ground into flour. Before analysis, the sample was additionally dried at a temperature of $102 \pm 2{ }^{\circ} \mathrm{C}$ and cooled in a desiccator. 
The moisture content, the amount of total nitrogen and ash were determined by the above methods in triplicate repetition. Lipid content was determined by extraction of mushroom samples (absolutely dry weight) in petroleum ether as a solvent using a Soxhlet extractor.

The total nitrogen content per crude protein content was calculated using a coefficient of 4.38 in terms of the amount digested in the human body [16].
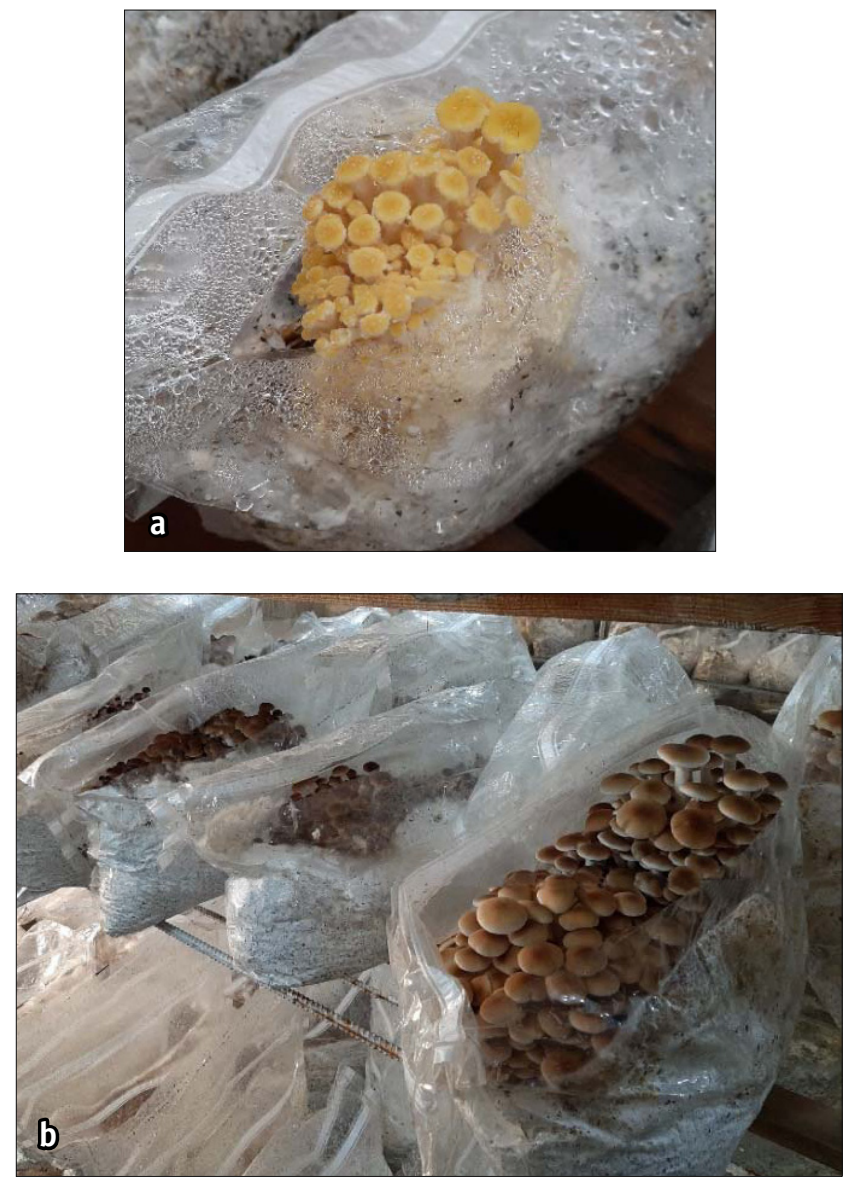

Fig. 1. Types of holes on polypropylene bags for fruiting stimulation:

a) two cuts $100 \pm 20 \mathrm{~mm}$ for $P$. citrinopileatus;

b) one large incision for $S$. aegerita

Endopolysaccharides (endoPS) were extracted from dry matter according to the following procedure: $2 \mathrm{~g}$ of fruiting bodies powder were added to $10 \mathrm{ml}$ of distilled water and thoroughly mixed; for 16 hours kept in an oven at a temperature of $98 \pm 0.1{ }^{\circ} \mathrm{C}$; the obtained extract was added with $96 \%$ ethyl alcohol in a ratio of $1: 2$ (by volume) to precipitate polysaccharides and settled for 24 hours at a temperature of $4{ }^{\circ} \mathrm{C}$. The precipitate was separated by centrifugation at $5000 \mathrm{RPM}$ for 25 minutes. The precipitate was dissolved by adding $20-30 \mathrm{ml}$ of hot deionized water $\left(90 \pm 1{ }^{\circ} \mathrm{C}\right)$. The suspended endopolysaccharide fraction was dried at $60{ }^{\circ} \mathrm{C}$ for 8 hours. The amount of endopolysaccharides in dry matter was determined gravimetrically and calculated by the formula: weight of endopolysaccharide / weight of sample $\times$ $100 \%$ [19].

The percentage of carbohydrates, excluding endopolysaccharides, was calculated using the formula: 100 - the amount of proteins (\%) the amount of lipids (\%) - the amount of ash elements (\%) - the amount of endopolysaccharides (\%). The $\mathrm{C} / \mathrm{N}$ ratio in the substrate was determined by the formula:

$C / N=0.52(100-a) / N$,

where $a$ - ash content, \%; 0.52 - averaged coefficient of carbon content; $N$ - total nitrogen content, \% [20].

The yield from each separate bag was calculated by the ratio of the mass of the harvested mushrooms in grams per kilogram of the prepared substrate mass.

The biological efficiency (BE) of cultivars was calculated using the formula:

$$
B E=\frac{M_{f b}}{M_{d m}} \times 100 \%
$$

where $M_{f b}$ - mass of raw fruit bodies; $M_{d m}-$ mass of the substrate dry matter [21].

Statistical analysis of the obtained results was carried out using the Microsoft Office Excel 2016 MSO package and the built-in QI Macros 2020 program. One and two-factor ANOVA analysis was performed («a» is the highest indicator in the experiment), to compare the mean in the groups, the U-test (Mann-Whitney). The smallest significant difference was found using the significance level $=0.05$.

\section{Results and discussion}

Based on the results of the analysis of the content of the prepared substrate compositions, the differences in the indicators of the content of ash elements and density were determined (Table 2).

In SC1 and SC2 substrates, which included straw, high ash content was determined in comparison with SC3, where only sunflower waste was used. The latter corresponds to the literature data on the composition of raw materials [22]. Also, the SC3 substrate significantly differed from others in terms of density $\left(568 \pm 21 \mathrm{~kg} / \mathrm{m}^{3}\right)$, which is associated with the absence of a sufficiently large fraction of straw. The indicators of moisture content and the content of the main nutrients in the calculated compositions did not differ, which indicates the possibility of theoretical calculation of the substrate formula based on the results of the analysis of raw materials. According to the 
Table 2

Characteristic of substrate compositions in the experiment

(mean \pm standard error)

\begin{tabular}{|l|c|c|c|c|c|}
\hline Code & Moisture (\%) & Total nitrogen $(\%)$ & Ash (\%) & C/N ratio & Density $(\mathrm{kg} / \mathrm{mi})$ \\
\hline SC1 & $63.4 \pm 1.8$ & $2.25 \pm 0.21$ & $4.6 \mathrm{a} \pm 0.4$ & $21.2 \pm 0.8 / 1$ & $337 \mathrm{~b} \pm 29$ \\
SC2 & $65.9 \pm 1.7$ & $2.38 \pm 0.15$ & $4.8 \mathrm{a} \pm 0.7$ & $20.0 \pm 1.3 / 1$ & $315 \mathrm{~b} \pm 42$ \\
SC3 & $63.9 \pm 2.1$ & $2.29 \pm 0.29$ & $3.6 \mathrm{~b} \pm 0.5$ & $21.1 \pm 1.0 / 1$ & $568 \mathrm{a} \pm 21$ \\
\hline LSD $_{0.05}$ & 1.9 & 0.25 & 0.93 & 1.7 & 75 \\
\hline
\end{tabular}

results of statistical analysis, a significant effect of the substrate composition content on the term of vegetative development of crops in the substrate (its end was determined by the date of the first primordia formation), as well as on the indicators of the total yield and biological efficiency of cultivars was proved (Table 3).

Indicators of cultivation of $C$. aegerita and $P$. citrinopileatus

(average over 3 growing cycles \pm standard error) (2019-2020)

\begin{tabular}{|c|c|c|c|c|c|}
\hline \multicolumn{1}{|c|}{ Culture } & SC & $\begin{array}{c}\text { Primordia } \\
\text { formation (day) }\end{array}$ & Harvesting (day) & Total yield (g/kg) & $\begin{array}{c}\text { Biological } \\
\text { efficiency (\%) }\end{array}$ \\
\hline C. aegerita & 1 & $25.3 \mathrm{c} \pm 1.45$ & $35.22 \mathrm{~b} \pm 1.66$ & $122.7 \mathrm{a} \pm 23.1$ & $31.46 \mathrm{~b} \pm 5.92$ \\
& 2 & $28.2 \mathrm{~b} \pm 0.80$ & $38.20 \mathrm{ab} \pm 1.36$ & $123.3 \mathrm{a} \pm 22.7$ & $35.27 \mathrm{ab} \pm 6.48$ \\
& 3 & $29.8 \mathrm{ab} \pm 0.41$ & $38.58 \mathrm{ab} \pm 0.35$ & $132.1 \mathrm{a} \pm 11.5$ & $33.87 \mathrm{ab} \pm 2.95$ \\
\hline \multirow{3}{*}{ P. citrinopileatus } & 1 & $26.3 \mathrm{bc} \pm 1.62$ & $41.18 \mathrm{a} \pm 2.43$ & $167.5 \mathrm{a} \pm 27.2$ & $42.95 \mathrm{ab} \pm 6.96$ \\
& 2 & $24.8 \mathrm{c} \pm 1.02$ & $40.00 \mathrm{a} \pm 2.51$ & $170.5 \mathrm{a} \pm 15.2$ & $48.71 \mathrm{a} \pm 4.35$ \\
& 3 & $32.0 \mathrm{a} \pm 0.95$ & $39.60 \mathrm{ab} \pm 1.25$ & $45.5 \mathrm{~b} \pm 4.6$ & $11.66 \mathrm{c} \pm 1.18$ \\
\hline $\mathrm{LSD}_{0.05}$ & - & 3.2 & 4.51 & 58.9 & 15.22 \\
\hline$p$ & - & 0.001 & 0.156 & 0.013 & 0.007 \\
\hline
\end{tabular}

The shortest terms of primordia formation in the experiment were recorded when $P$. citrinopileatus was grown on the SC2 substrate composition, and the longest, also for this culture, on the SC3 substrate $(24.80 \pm 1.02$ and $32.00 \pm 0.95$ days, respectively).

The cultures colonized the substrates and began to form primordia at different times. The fastest development of $C$. aegerita was determined on $\mathrm{SC} 1$ substrate $(25.33 \pm 1.45$ days $)$, while the $P$. citrinopileatus culture was more active on SC2 (24.80 \pm 1.02 days). It should be noted that primordia appeared on SC3 substrate in both cultures much later: C. aegerita on $29.84 \pm 0.41$ day, and P. citrinopileatus on $32.00 \pm 0.95$ day.

There was no significant difference between the end of the harvest for grown crops by twofactor analysis of ANOVA data $(p=0.156)$, but after comparing means of the groups by the Mann-Whitney U-Test method, a significantly longer duration of fruiting $(p<0.05)$ was determined for $P$. citrinopileatus culture. The shortest cycle in the experiment had C. aegerita culture grown on SC1 substrate (35.22 \pm 1.66 days).

The substrate composition significantly ( $p=$ 0.013 ) influenced the yield of the studied species. In the experiment, the largest mass of fruiting bodies was collected on $P$. citrinopileatus culture on SC1 and SC2 (167.5 \pm 27.2 and
$170.5 \pm 15.2 \mathrm{~g}$ per $1 \mathrm{~kg}$ of substrate, respectively). The lowest yield in the experiment $(45.5 \pm 4.6 \mathrm{~g} / \mathrm{kg})$ was also determined for this crop on SC3 substrate.

The overall yield of $C$. aegerita cultivar in the experiment $(122.7 \ldots 132.1 \mathrm{~g} / \mathrm{kg})$ was lower than the known scientific data. For example, when using a composition of wheat straw, chicken litter and millet seeds in a ratio of $70: 20: 10$, researchers received up to $770.5 \pm 118.4 \mathrm{~g}$ of fresh mushrooms from $5000 \mathrm{~g}$ of substrate [12]. But the results obtained in the experiment significantly exceed the yield indicators for C. aegerita, grown on birch sawdust $(87 \mathrm{~g} / \mathrm{kg})$ [13]. The obtained indicators of $P$. citrinopileatus productivity confirm the results [4] with the definition of low efficiency of this species when using substrates with high density. Also, the yield indicators practically coincided when grown on similar plant residues: on straw $109.6 \mathrm{~g}$, sugar cane $-177.1 \mathrm{~g}$.

According to the results of statistical analysis, a significant effect of the composition of the substrate on the biological efficiency (BE) of $P$. citrinopileatus culture $(p=0.006)$ was determined, while for $C$. aegerita culture, no significant difference was found in this indicator between the experimental options ( $p=0.877$ ). The highest $\mathrm{BE}$ in the experiment was obtained under the conditions of $P$. citrinopileatus cultiva- 
tion on SC2 substrate $(48.71 \pm 4.35 \%)$, and the lowest $(11.66 \pm 1.18 \%)$ - on the SC3 substrate for the same culture. The $\mathrm{BE}$ index of C. aegerita in the experiment varied slightly from $31.46 \pm 5.92 \%$ (SC1) to $35.27 \pm 6.48 \%$ (SC2). It should be noted that the results of the analysis were higher compared to the indicators of $\mathrm{BE}$ of C. aegerita, obtained by American scien- tists [12] when using substrates with a low ratio of carbon to nitrogen $(\mathrm{C} / \mathrm{N})$, where $\mathrm{BE}$ was $6.3 \pm 2.4 \%$ for $\mathrm{C} / \mathrm{N}=13 / 1$ and $9.4 \pm 4.1 \%$ for $\mathrm{C} / \mathrm{N}=30 / 1$. As a result of the analysis of the obtained data, a significant influence of substrates on the chemical composition of the fruiting bodies of the studied species was determined (Table 4).

Chemical parameters of fruiting bodies of $C$. aegerita and $P$. citrinopileatus according to experimental variants

\begin{tabular}{|c|c|c|c|c|c|c|c|}
\hline Species & SC & $\begin{array}{c}\text { Crude protein } \\
(\%)\end{array}$ & Lipids (\%) & $\begin{array}{c}\text { Endopolysaccharides } \\
(\%)\end{array}$ & $\begin{array}{c}\text { Other } \\
\text { polysaccharides (\%) }\end{array}$ & Ash (\%) & Dry matter (\%) \\
\hline \multirow{2}{*}{ C. aegerita } & 1 & $19.62 \mathrm{ab} \pm 0.30$ & $2.59 \mathrm{a} \pm 0.08$ & $3.38 \mathrm{bc} \pm 0.89$ & $72.79 \pm 1.15$ & $1.64 \mathrm{~b} \pm 0.55$ & $8.67 \mathrm{~b} \pm 0.49$ \\
& 2 & $20.53 \mathrm{ab} \pm 0.6$ & $2.77 \mathrm{a} \pm 0.56$ & $1.38 \mathrm{c} \pm 0.25$ & $73.86 \pm 0.83$ & $1.47 \mathrm{~b} \pm 0.35$ & $10.52 \mathrm{a} \pm 0.15$ \\
& 3 & $21.78 \mathrm{a} \pm 0.52$ & $2.30 \mathrm{ab} \pm 0.10$ & $6.81 \mathrm{a} \pm 0.41$ & $61.45 \pm 1.12$ & $7.47 \mathrm{a} \pm 0.17$ & $10.11 \mathrm{a} \pm 0.23$ \\
\hline \multirow{3}{*}{ P. citrinopileatus \pm} & 1 & $17.38 \mathrm{~b} \pm 2.60$ & $1.41 \mathrm{~b} \pm 0.19$ & $4.72 \mathrm{~b} \pm 0.61$ & $67.38 \pm 1.64$ & $9.12 \mathrm{a} \pm 1.42$ & $10.33 \mathrm{a} \pm 0.29$ \\
& 2 & $20.45 \mathrm{ab} \pm 0.90$ & $1.41 \mathrm{~b} \pm 0.05$ & $3.12 \mathrm{bc} \pm 0.95$ & $64.90 \pm 1.80$ & $10.14 \mathrm{a} \pm 1.19$ & $8.87 \mathrm{~b} \pm 0.05$ \\
& 3 & $22.47 \mathrm{a} \pm 0.19$ & $1.63 \mathrm{~b} \pm 0.41$ & $2.54 \mathrm{c} \pm 0.54$ & $65.90 \pm 1.63$ & $7.65 \mathrm{a} \pm 0.26$ & $8.22 \mathrm{~b} \pm 0.03$ \\
\hline \multicolumn{2}{|c|}{$\mathrm{LSD}_{0.05}$} & 3.63 & 0.93 & 2.03 & - & 2.76 & 0.80 \\
\hline$p$ & 0.111 & 0.021 & 0.001 & - & 0.0001 & 0.0001 \\
\hline
\end{tabular}

The highest protein content in the experiment $(22.47 \pm 0.19 \%)$ was found in the fruiting bodies of P. citrinopileatus, grown on SC3 substrate, and the lowest for the same species $(17.38 \pm 2.60 \%)$ when SC1 was used. It should be noted that in both cultivars, fruiting bodies obtained from SC3 had the highest amount of proteins, while those grown on SC1 had the least.

The lipid content in the fruiting bodies of C. aegerita was significantly higher $(p=0.021)$ compared to that in P. citrinopileatus, but the factor of the influence of the substrate composition on the total amount of fats for individual cultivars was insignificant. The maximum amount of lipids $(2.77 \pm 0.56 \%)$ was contained in the fruiting bodies of $C$. aegerita obtained from SC2, and the lowest in the fruiting bodies of P. citrinopileatus on substrates SC1 and SC2 $(1.41 \%)$.

According to the results of statistical analysis of the data, significant differences were proved in terms of the content of endopolysaccharides in fruiting bodies of cultivars obtained on different substrates $(p=0.001)$. In particular, a high amount of endopolysaccharides $(6.81 \pm 0.41 \%)$ was isolated from the fruiting bodies of $C$. aegerita, grown on SC3, and the smallest $(1.38 \pm 0.25 \%)$ on SC1. The content of endopolysaccharides in the fruiting bodies of $P$. citrinopileatus had less variability from $2.54 \pm 0.54$ (SC3) to $4.72 \pm 0.61 \%$ (SC1). Indicators of the content of other polysaccharides were calculated, but their greatest value was recorded in the fruiting bodies of $C$. aegerita on $\mathrm{SC} 2$ substrate $(73.86 \pm 0.83 \%)$, the smallest value also for this cultivar, on SC3 substrate $(61.45 \pm 1.12 \%)$.

As a result of comparing the means by the Mann-Whitney U-Test method, a significant difference was determined between the studied crops in terms of ash content. The highest index was observed for the fruiting bodies of P. citrinopileatus obtained from SC2 substrate $(10.14 \pm 1.19 \%)$, the lowest - for the fruiting bodies of $C$. aegerita from substrates of the same composition $(1.47 \pm 0.35 \%)$.

Based on the results of two-factor statistical analysis, a significant effect of the content of substrate compositions on the content of dry matter (DM) in the fruiting bodies of cultivars was determined. The highest DM content was observed in C. aegerita mushrooms from SC2 substrate $(10.52 \pm 0.15 \%)$, the lowest - in P. citrinopileatus from SC3 $(8.22 \pm 0.03 \%)$. According to univariate analysis, the fruiting bodies of P. citrinopileatus grown on SC1 substrate had the highest DM content $(10.33 \pm 0.29 \%)$, while the fruiting bodies of $C$. aegerita on the same substrate had the lowest one $(8,67 \pm 0.49 \%)$.

The chemical composition of the obtained fruiting bodies coincides with the results of previous researchers [23]. For example, under the conditions of $C$. aegerita cultivation on substrates with the addition of fermented chicken manure, the lipid content in the fruiting bodies varied from 1.02 to $2.28 \%$, while the content of crude proteins varied from 27.1 to $37.6 \%$ when using the composition «straw / waste / millet» in the ratio $70: 10: 20$ [12]. According to Musieba [24], the fruiting bodies of the golden oyster mushroom contained $22.10 \pm 2.03 \%$ crude pro- 
teins on substrates containing straw. So, the investigated substrate compositions make it possible to obtain the fruiting bodies of $P$. citrinopileatus and $C$. aegerita with satisfactory indicators of nutritional value.

\section{Conclusions}

The possibility of using agricultural byproducts for the effective cultivation of wooddecay fungi $P$. citrinopileatus and $C$. aegerita was investigated. The significant influence of the composition of substrates on technological and chemical parameters of the studied crops was determined. The efficiency of using a substrate composition from barley straw, fuel pellets from sunflower husk, rapeseed, corn flour, and $\mathrm{CaCO}_{3}$ in a ratio of $40: 90: 20: 25: 1$ by mass fractions was proven. The obtained results made it possible to assess positively nutritional value of fruit bodies by the content of crude proteins in terms of the amount digested in the human body - from 17.38 to $22.47 \%$ in dry matter in P. citrinopileatus and from 19.62 to $21.78 \%$ in C. aegerita. The presence of endopolysaccharides in the fruiting bodies of $P$. citrinopileatus (2.54-4.72\%) and $C$. aegerita (1.38$6.81 \%$ ) indicates the possibility of their use as a source of functional substances in therapeutic nutrition.

\section{References}

1. Prasad, S., Rathore, H., Sharma, S., \& Yadav, A. S. (2015). Medicinal mushrooms as a source of novel functional food. Int. J. Food Sci. Nutr. Diet., 04(5), 221-225. doi: 10.19070/2326-33501500040

2. Royse, D. J., Baars, J., \& Tan, Q. (2017). Current overview of mushroom production in the world. In C. Zied Diego, \& A. Pardo-Giménez (Eds.), Edible and medicinal mushrooms: technology and applications (pp. 5-13). New York, NY: John Wiley \& Sons. doi: 10.1002/9781119149446.ch2

3. Miyazawa, M., Dejima, Y., Takahashi, T., Matsuda, N., \& Ishikawa, R. (2011). Characteristic Odor Components of Essential Oil from Dried Fruiting Bodies of Golden Oyster Mushroom (Pleurotus citrinopileatus). J. Essent. Oil Res., 23(3), 58-63. doi: 10.1080/ 10412905.2011.9700459

4. Musieba, F., \& Okoth, S. (2011). First record of the occurrence of Pleurotus citrinopileatus Singer on new hosts in Kenya. Agric. Biol. J. NorthAm.,2(9),1304-1309. doi:10.5251/abjna.2011.2.9.1304.1309

5. Tarnopol'skaya, V. V., Alaudinova, E. V., Savolaynen, A. S., \& Roptopulo, S. I. (2014). Chemical composition of Pleurotus xylotroph basidiomycetes in submerged culture. Hvojnye boreal'noj zony [Conifers of the Boreal Area], 32(1-2), 78-80. [in Russian]

6. Chen, P. H., Weng, Y. M., Lin, S. M., Yu, Z. R., \& Wang, B. J. (2017). Molecular weight affected antioxidant, hypoglycemic and hypotensive activities of cold-water extract from Pleurotus citrinopileatus. J. Food Sci., 82(10), 2456-2461. doi: 10.1111/17503841.13851

7. Minato, K. I. (2008). Immunomodulation activity of a polysaccharide fraction of a culinary-medicinal mushroom, Pleurotus citrinopileatus Singer (Agaricomycetideae), in vitro. Int. J. Med. Mushrooms, 10(3), 235-244. doi: 10.1615/IntJMedMushr.v10.i3.40

8. Sheng, Y., Zhao, C., Zheng, S., Mei, X., Huang, K., Wang, G., \& He, X. (2019). Anti-obesity and hypolipidemic effect of water extract from Pleurotus citrinopileatus in $\mathrm{C} 57 \mathrm{BL} / 6 \mathrm{~J}$ mice. Food Sci. Nutr., 7(4), 1295-1301. doi: 10.1002/fsn3.962

9. Bandura, I. I., Kulyk, A. S., \& Koliadenko, V. V. (2020). Xylotrophic mushrooms as a source of bioactive substances for functional nutrition. Praci Tavrijs'kogo deržavnogo agrotehnologičnogo universitetu [Proceedings of the Tavria State Agrotechnological University], 20(2), 132-140. doi: 10.31388/20780877-20-2-132-141 [in Ukrainian]

10. Diyabalanage, T., Mulabagal, V., Mills, G. L., DeWitt, D. L., \& Nair, M. G. (2008). Health-beneficial qualities of the edible mushroom, Agrocybe aegerita. Food Chem., 108(1), 97-102. doi: 10.1016/j.foodchem.2007.10.049

11. Jing, H., Li, J., Zhang, J., Wang, W., Li, S., Ren, Z., ... Jia, L. (2018). The antioxidative and anti-aging effects of acidicand alkalic-extractable mycelium polysaccharides by Agrocybe aegerita (Brig.) Sing. Int. J. Biol. Macromol., 106, 1270-1278. doi: 10.1016/j.ijbiomac.2017.08.138

12. Isikhuemhen, 0. S., Mikiashvili, N. A., \& Kelkar, V. (2009). Application of solid waste from anaerobic digestion of poultry litter in Agrocybe aegerita cultivation: mushroom production, lignocellulolytic enzymes activity and substrate utilization. Biodegradation, 20(3), 351-361. doi: 10.1007/s10532-008-9226-y

13. Jasińska, A., Siwulski, M., \& Sobieralski, K. (2012). Mycelium growth and yielding of black poplar mushroom - Agrocybe aegerita (Brig.) Sing. on different substrates. J. Agric. Sci. Technol., 2(9), 1040-1047.

14. Kleofas, V., Sommer, L., Fraatz, M. A., Zorn, H., \& Rühl, M. (2014). Fruiting body production and aroma profile analysis of Agrocybe aegerita cultivated on different substrates. Nat. Res., 5(6), 233-240. doi: 10.4236/nr.2014.56022

15. Bandura, I., Kulyk, A., Chausov, S., \& Tsyz, 0. (2020). Influence of plant substrate composition on the efficiency of edible mushrooms cultivation Cyclocybe aegerita (V.Brig.), Pleurotus eryngii (DC.) Quel., Pleurotus citrinopileatus Singer and Flammulina velutipes (Curtis) Singer. Visnik agrarnoï nauki Pričornomor'â [Ukrainian Black Sea Region Agrarian Science], 3, 62-71. doi: 10.31521/2313-092X/2020-3(107)-8 [in Ukrainian]

16. Bukhalo, A. S., \& Dudka, I. A. (1988). Vysshiye syedobnyye bazidiomitsety $v$ chistoy kulture [Higher edible basidiomycetes in pure culture]. Kyiv: Naukova dumka. [in Ukrainian]

17. Wanzenböck, E., Apprich, S., Tirpanalan, Ö., Zitz, U., Kracher, D., Schedle, K., \& Kneifel, W. (2017). Wheat bran biodegradation by edible Pleurotus fungi - A sustainable perspective for food and feed. LWT - Food Science and Technology, 86, 123-131. doi: 10.1016/j.lwt.2017.07.051

18. Pardo-Giménez, A., Catalán, L., Carrasco, J., Álvarez-Ortí, M., Zied, D., \& Pardo, J. (2016). Effect of supplementing crop substrate with defatted pistachio meal on Agaricus bisporus and Pleurotus ostreatus production. J. Sci. Food Agric., 96(11), 38383845. doi: $10.1002 /$ jsfa.7579

19. Boromenskyi, D. 0., \& Bisko, N. A. (2020). Influence of cultivation conditions on biomass and endopolysaccharide production by species of the genus Ganoderma (Ganodermataceae). Ukr. Bot. J., 77(2), 117-124. doi: 10.15407/ukrbotj77.02.117 [in Ukrainian]

20. Zenova, G. M., Stepanov, A. L., Likhacheva, A. A., \& Manucharova, N. A. (2002). Praktikum po biologii pochv [Soil Biology Workshop]. Moscow: Izdatel'stvo Moskovskogo universiteta. [in Russian]

21. Chang, S. T., \& Hayes, W. A. (Eds.). (2013). The biology and cultivation of edible mushrooms. New York, NY: Academic Press.

22. Harkov, V. V., Tuncev, D. V., \& Kuznecov, M. G. (2018). Thermochemical processing of sunflower husk. Vestnik Kazanskogo gosudarstvennogo agrarnogo universiteta [Vestnik of Kazan State Agrarian University], 4, 130-134. doi: 10.12737/ article_5c3de39d111083.70940804 [in Russian]

23. Shevale, S. B., \& Deshmukh, H. V. (2016). Yield performance and nutritional analysis of Pleurotus species on different agro wastes and vegetable wastes. Int. J. Plant Prot., 9(1), 162-167. doi: 10.15740/HAS/IJPP/9.1/162-167 
24. Musieba, F., Okoth, S., Mibey, R. K., Wanjiku, S., \& Moraa, K. (2013). Proximate composition, amino acids and vitamins profile of Pleurotus citrinopileatus Singer: an indigenous mushroom in Kenya. Am. J. Food Technol., 8(3), 200-206. doi: 10.3923/ ajft.2013.200.206

\section{Використана література}

1. Prasad S., Rathore H., Sharma S., Yadav A. S. Medicinal mushrooms as a source of novel functional food. Int. J. Food Sci. Nutr. Diet. 2015. Vol. 04, Iss. 5. P. 221-225. doi: 10.19070/23263350-1500040

2. Royse D. J., Baars J., Tan Q. Current overview of mushroom production in the world. Edible and medicinal mushrooms: Technology and applications / C. Zied Diego, A. Pardo-Giménez (Eds.). New York, NY : John Wiley \& Sons, 2017. P. 5-13. doi: 10.1002/9781119149446.ch2

3. Miyazawa M., Dejima Y., Takahashi T. et al. Characteristic Odor Components of Essential Oil from Dried Fruiting Bodies of Golden Oyster Mushroom (Pleurotus citrinopileatus). J. Essent. Oil Res. 2011. Vol. 43, Iss. 3. P. 58-63. doi: 10.1080/10412905. 2011.9700459

4. Musieba F., Okoth S. First record of the occurrence of Pleurotus citrinopileatus Singer on new hosts in Kenya. Agric. Biol. J. North Am. 2011. Vol. 2, Iss. 9. P. 1304-1309. doi: 10.5251/abjna.2011.2.9.1304.1309

5. Тарнопольская В. В., Алаудинова Е. В., Саволайнен А. С., Роптопуло С. И. Химический состав глубинной культуры ксилотрофных базидиомицетов рода Pleurotus. Хвойные бореальной зоны. 2014. Т. 32, № 1-2. С. 78-80.

6. Chen P. H., Weng Y. M., Lin S. M. et al. Molecular weight affected antioxidant, hypoglycemic and hypotensive activities of coldwater extract from Pleurotus citrinopileatus. J. Food Sci. 2017. Vol. 82, Iss. 10. P. 2456-2461. doi: 10.1111/1750-3841.13851

7. Minato K. I. Immunomodulation activity of a polysaccharide fraction of a culinary-medicinal mushroom, Pleurotus citrinopileatus Singer (Agaricomycetideae), in vitro. Int. J. Med. Mushrooms. 2008. Vol. 10, Iss. 3. P. 235-244. doi: 10.1615/IntJMedMushr.v10.i3.40

8. Sheng Y., Zhao C., Zheng S. et al. Anti-obesity and hypolipidemic effect of water extract from Pleurotus citrinopileatus in C57 BL/6J mice. Food Sci. Nutr. 2019. Vol. 7, Iss. 4. P. 12951301. doi: 10.1002/fsn3.962

9. Бандура I. І., Кулик А. С., Коляденко В. В. Ксилотрофні гриби як джерело біоактивних речовин для функціонального харчування. Праці Таврійського держ. агротехнол. ун-ту. 2020. Т. 2, Вип. 20. С. 132-140. doi: 10.31388/2078-0877-20-2$132-141$

10. Diyabalanage T., Mulabagal V., Mills G. et al. Health-beneficial qualities of the edible mushroom, Agrocybe aegerita. Food Chem. 2008. Vol. 108, Iss. 1. P. 97-102. doi: 10.1016/j.foodchem.2007.10.049

11. Jing H., Li j., Zhang J. et al. The antioxidative and anti-aging effects of acidic-and alkalic-extractable mycelium polysaccharides by Agrocybe aegerita (Brig.) Sing. Int. J. Biol. Macromol. 2018. Vol. 106. P. 1270-1278. doi: 10.1016/j.ijbiomac.2017.08.138

12. Isikhuemhen 0. S., Mikiashvili N. A., Kelkar V. Application of solid waste from anaerobic digestion of poultry litter in Agrocybe aegerita cultivation: mushroom production, lignocellulolytic enzymes activity and substrate utilization. Biodegradation. 2009. Vol. 20, Iss. 3. P. 351-361. doi: 10.1007/s10532-008-9226-y

13. Jasińska A., Siwulski M., Sobieralski K. Mycelium growth and yielding of black poplar mushroom - Agrocybe aegerita (Brig.) Sing. on different substrates. J. Agric. Sci. Technol. 2012. Vol. 2, Iss. 9. P. 1040-1047.

14. Kleofas V., Sommer L., Fraatz M. A. et al. Fruiting body production and aroma profile analysis of Agrocybe aegerita cultivated on different substrates. Nat. Res. 2014. Vol. 5, Iss. 6. P. 233-240. doi: 10.4236/nr.2014.56022

15. Бандура I. І., Кулик А. С., Чаусов С. В., Цизь О. М. Вплив складу рослинних субстратів на ефективність культивування їстівних грибів Cyclocybe aegerita (V.Brig.), Pleurotus eryngii (DC.) Quel., Pleurotus citrinopileatus Singer ta Flammulina velutipes (Curtis) Singer. Вісн. аграр. науки Причорномор'я. 2020. № 3. С. 62-71. doi: 10.31521/2313-092X/2020-3(107)-8

16. Бухало А. С., Дудка И. А. Высшие съедобные базидиомицеты в чистой культуре. Киев : Наукова думка, 1988. 144 с.

17. Wanzenböckab E., Apprichab S., Tirpanalanab Ö. et al. Wheat bran biodegradation by edible Pleurotus fungi - A sustainable perspective for food and feed. LWT - Food Sci. Technol. 2017. Vol. 86. P. 123-131. doi: 10.1016/j.lwt.2017.07.051

18. Pardo-Giménez A., Catalán L., Carrasco J. et al. Effect of supplementing crop substrate with defatted pistachio meal on Agaricus bisporus and Pleurotus ostreatus production. J. Sci. Food Agric. 2016. Vol. 96, Iss. 11. P. 3838-3845. doi: 10.1002/jsfa.7579

19. Бороменський Д. 0., Бісько Н. А. Вплив умов культивування на накопичення біомаси та ендополісахаридів грибами роду Ganoderma (Ganodermataceae). Ukr. Bot. J. 2020. T. 77, № 2 . C. 117-123. doi: 10.15407/ukrbotj77.02.117

20. Зенова Г. М., Степанов А. Л., Лихачева А. А., Манучарова Н. А. Практикум по биологии почв. Москва : Изд-во МГУ, 2002. 120 с.

21. The biology and cultivation of edible mushrooms / S. T. Chang \& W. A. Hayes (Eds.). New York, NY : Academic press, 2013. $842 \mathrm{p}$.

22. Харьков В. В., Тунцев Д. В., Кузнецов М. Г. Термохимическая переработка лузги подсолнечника. Вестник КазанСКого ГАУ. 2018. № 4. С. 130-134. doi: 10.12737/article_ 5c3de39d111083.70940804

23. Shevale S. B., Deshmukh H. V. Yield performance and nutritional analysis of Pleurotus species on different agro wastes and vegetable wastes. Int. J. Plant Prot. 2016. Vol. 9, Iss. 1. P. 162-167. doi: 10.15740/HAS/IJPP/9.1/162-167

24. Musieba F., Okoth S., Mibey R. K. et al. Proximate composition, amino acids and vitamins profile of Pleurotus citrinopileatus Singer: an indigenous mushroom in Kenya. Am. J. Food Technol. 2013. Vol. 8, Iss. 3. P. 200-206. doi: 10.3923/ ajft.2013.200.206

\section{УДК 635.89/577.11}

Бандура I. I. ${ }^{*}$, Кулик А. С. ${ }^{1}$, Макогон С. В. ${ }^{1}$, Хареба О. В. ${ }^{2}$, Хареба В. В. ${ }^{2}$ Вплив складу субстрату на врожайність і показники харчової цінності плодових тіл їстівних грибів Pleurotus citrinopileatus та Cyclocybe aegerita. Plant Varieties Studying and Protection. 2021. T. 17, № 2. C. 130-138. https://doi.org/10.21498/25181017.17.2.2021.236519

${ }^{1}$ Таврійський державний агротехнологічний університет імені Дмитра Моторного, пр-m Б. Хмельницького, 18, м. Мелітополь, Запорізька обл., 72312, Україна, ”e-mail: irabandura@gmail.com

${ }^{2}$ Національна академія аграрних наук України, вул. М. Омельяновича-Павленка, 9, м. Київ, 01010, Україна

Мета. Установити вплив складу субстратних композицій на технічні-показники та хімічний склад плодових тіл гливи золотої та опенька тополевого. Методи. Схема експерименту включала вирощування двох видів дереворуйнівних грибів Pleurotus citrinopileatus Singer (штам
2161 ІВК) та Cyclocybe aegerita (V.Brig.) Vizzini (штам 2230 ІВК) на трьох варіантах субстратних композицій. Застосовано лабораторні, лабораторно-виробничі методи оцінки ефективності технології вирощування, хімічного складу отриманої сировини, статистичні методи 
аналізу. Результати. Структура та склад субстратів впливають на технологічні характеристики культури, фізичні та хімічні властивості плодових тіл. Найкоротший цикл плодоношення у $35,2 \pm 1,7$ доби визначено для культури C. aegerita за умов вирощування на субстраті СК1 з формулою «солома / лушпиння / гранули / ріпак / кукурудза / крейда» у співвідношенні $30: 40: 70: 20: 20: 1$. Найвищу врожайність $(170,5 \pm 15,2$ г на 1 кг субстрату) у досліді визначено для P. citrinopileatus на субстраті СК2 з формулою «солома / гранули / ріпак / кукурудза / крейда» у співвідношенні $40: 90: 20: 25: 1$. Плодові тіла $P$. citrinopileatus, отримані із субстрату СК3 з формулою «гранули / ріпак / кукурудза / крейда» у співвідношенні $60: 110: 20: 30: 1$, мали найвищий у досліді вміст білків - 22,47 $\pm 0,19 \%$, а найменшу кількість білків - 17,38 $\pm 2,60 \%$ - мали плодові тіла із субстрату СК1. Плодові тіла C. aegerita містили більше ліпідів порівняно з плодовими тілами $P$. citrinopileatus, але чинник впливу складу субстрату на загальну кількість ліпідів для деяких культиварів виявився несуттєвим. Найвищу кількість ендополісахаридів виділено з плодових тіл C. aegerita $(6,81$ $\pm 0,41 \%)$, отриманих із субстрату СК3, а найменшу - у варіанті СК1 (1,38 \pm 0,25\%). Уміст ендополісахаридів у плодових тілах $P$. citrinopileatus мав меншу варіативність: від $2,54 \pm 0,54$ (СК3) до 4,72 $\pm 0,61 \%$ (СК1). Висновки. Склад субстратних композицій суттєво впливає на біологічну ефективність культиварів та вміст нутрієнтів у плодових тілах досліджених видів. Отримані результати дають змогу грибівникам спрогнозувати ефективність виробництва та якість отриманих грибів відповідно до використання доступної сировини.

Ключові слова: культивування грибів; глива золота; опеньок тополевий; біологічна ефективність; хімічний склад. 